\title{
Effect of sugar on changes in the denaturation of fish myofibrillar protein and the state of water during frozen storage
}

\author{
KATSUMI SAKAGUCHI ${ }^{1}$,YUSUKE SHIKU ${ }^{2}$ and YUKINORI NOZAKI ${ }^{3}$ \\ IIndustrial Technology Center of Nagasaki, Ikeda 2-1303-8, Omura 856-0026, Japan \\ ${ }_{2}^{2}$ Graduate School of Science and Technology, Nagasaki University, Bumkyo 1-14, Nagasaki 852-8521, Japan \\ ${ }_{3}^{3}$ Faculty of Fisheries, Nagasali University, Bunkyo 1-14, Nagasaki 852-8521, Japan
}

KEY WORDS: sugar, myofibril, denaturation, Ca-ATPase activity, unfrozen water, cryoprotectant

\section{INTRODUCTION}

The quality of fish meat gradually deteriorates upon freezing due to protein denaturation. To prevent such denaturation of protein during frozen storage, the additives such as saccharides, amino acids, organic acid, phosphates etc. are added to fish meat as potential cryoprotectant. 1-3) On the other hand, It is speculated that hydrated water around protein molecules suppresses denaturation and that these additives play a role in water retention. Especially, the preventive effects of sugars have been applied in the processing of frozen surimi. ${ }^{4,5}$ The amount of unfrozen water is also determined as an index of textural quality of foodstuffs. The basic purpose of the present study is to investigate the cryoprotective effect of 13 kinds of sugar on protein denaturation and the amount of unfrozen water by applying the technique of Ca-ATPase activity and differential scanning calorimetry, respectively during frozen storage at $-25^{\circ} \mathrm{C}$.

\section{MATERIALS AND METHODS}

A total of 13 sugars under the three major carbohydrate groups such as mono-, di- and trisaccharide were used in this study. The kind of the sugars is used below. Monosachride: pentose: arabinose, ribose and xylose; hexose: glucose, fructose, mannose and galactose; disaccharide: treharose, maltose, lactose, melibiose and sucrose; trisaccharide: raffinose. Carp (Cyprimus carpio) was purchased from the Kohda Fisheries Co. and used for preparation of myofibrils. Myofibrils were prepared by the method of Katoh et al. ${ }^{6}$ Myofibrils was placed in a mortar, and sugar was added at $5 \%$ to myofibrils and after the $\mathrm{pH}$ was adjusted to 7.0 with $0.01 \mathrm{~N} \mathrm{NaOH}$ or $0.01 \mathrm{~N} \mathrm{HCl}$ mixing thoroughly. The sample was sealed in a plastic bag and stored at $-25^{\circ} \mathrm{C}$. As the control, myofibrils without sugar was also processed and stored. The frozen specimens were taken out of the freezer after various days of storage. Then to remove sugar added, the specimen was mixed with

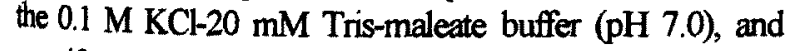
centrifuged $(750 \times \mathrm{g}, 10 \mathrm{~min}$.). This procedure was performed twice. The sample was suspended in the same buffer, and myofibrillar Ca-ATPase activity was measured as the following standard method. ATPase was assayed at $25^{\circ} \mathrm{C}$ in the reaction medium consisted of $100 \mathrm{mM} \mathrm{KCl}$, $5 \mathrm{mM} \mathrm{CaCl}, 25 \mathrm{mM}$ Tris-maleate ( $\mathrm{pH} \mathrm{7.0),} 1 \mathrm{mM} \mathrm{ATP}$, and $0.2-0.4 \mathrm{mg}$ myofibrils, the reaction was terminated by adding $30 \%$ trichloroacetic acid to give a final concentration of $5 \%$, and free inorganic phosphonic acid was then measured by colorimetry. Protein concentration was measured by the Biuret method using bovine serum albumin (fraction $\mathrm{V}$ ) as standard. The purity of the bovine serum albmin was corrected by Kjeldahl method.

The amount of the unfrozen water was measured by the method of a differential scanning calorimater (DSC-100 Seiko Electronic Industry, Co.). A sample of about $20 \mathrm{mg}$ was placed in an aluminum cell, while $20 \mathrm{mg}$ of $\mathrm{Al}_{2} \mathrm{O}_{3}$ was used in another cell as reference to balance the heat capacity of the sample cell. The heat of fusion was measured by elevating the temperature from $-40^{\circ} \mathrm{C}$ to $25^{\circ} \mathrm{C}$ at a rate of $1^{\circ} \mathrm{C}$ per minute by using liquid nitrogen gas. In the thermogram obtained by heating the endothermic peak was shown, peak area of which indicated amount of free water in the sample. Total water content in the sample was measured by drying at $105^{\circ} \mathrm{C}$ for 24 hours. Amount of unfrozen water in the sample was caluculated by subtracting free water from the amount of total water content.

\section{RESULTS}

Figures 1 and 2 show the changes in Ca-ATPase activity of carp myofibrils with 5\% sugar during frozen storage at $-25^{\circ} \mathrm{C}$. Myofibrils without sugar were used as a control. The Ca-ATPase activity of control decreased rapidly during frozen storage. The Ca-ATPase activity of myofibrils with sugar was decreased gradually during frozen storage, and its activity was higher than that of control at the same storage period. The cryoprotective effect of sugar to denaturation of myofibrils during frozen storage was independent of kinds of sugar. The other hand, the amount of unfrozen water of myofibrils with sugar was also decreased during frozen storage, but it was higher than that of control at the same storage period. A highly positive correlation was observed between the myofibrillar Ca-ATPase activity and the amount of frozen water. 


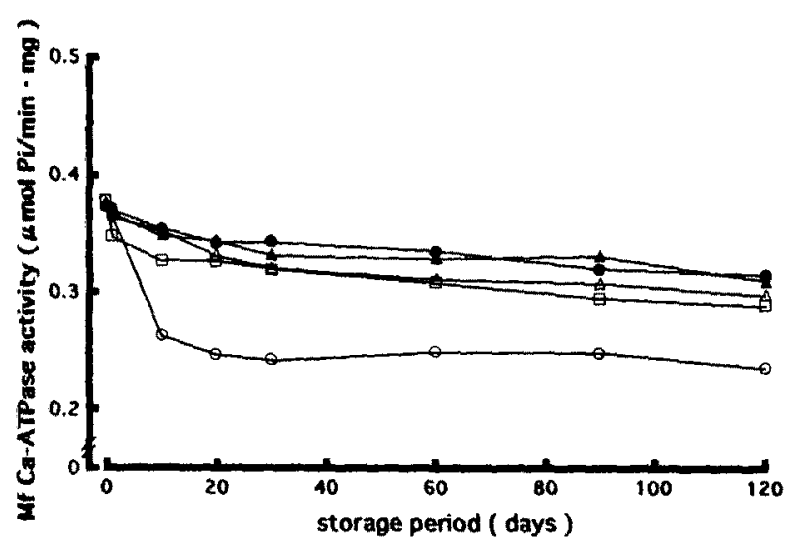

Fig I Changes in Ca-ATPase activity of myofibrils with adding various $5 \%$ hexoses during frozen storage at $-25^{\circ} \mathrm{C}$.

Symbols: ( $O$ ) control ( $O$ ) glucose, $(\triangle$ ) manmose,

( $\Delta$ ) fructose, $(\square)$ galactose.

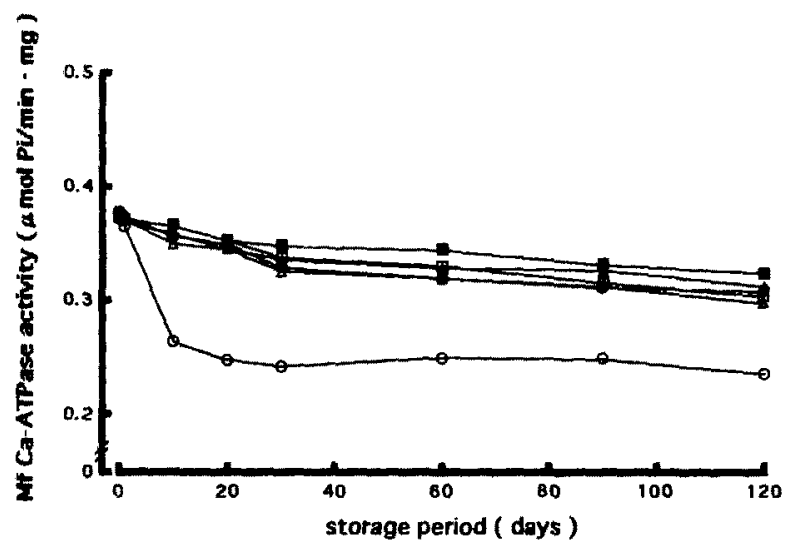

Fig 2 Changes in Ca-ATPase activity of myofibrils with adding vanious $5 \%$ disaccharides duning frozen storage at $-25^{\circ} \mathrm{C}$.

Symbols: ( $O$ ) control, ( $)$ ) sucrose, $(\Delta)$ treharose, ( $\Delta$ ) maltose, ( $\square$ ) lactose, ( $\square$ ) melibiose.

\section{DISCUSSION}

Numerous studies on the freeze denaturation of myofibrillar protein suggest the involvement of salt condensation, dehydration, interaction with degradation products, and $\mathrm{pH}$ change. However, the destruction of hydrogen bonds and reduction of the hydration layer surrounding polar residues of protein due to ice crystal formation is considered to be the major cause of denaturation. To prevent protein denaturation during frozen storage, sugars as the one of various cryoprotectants have been used popularly. The effect of water affinity by $\mathrm{OH}$ groups in structure is known as one of the functions of sugar. This indicated that the cryoprotect effect of sugar caused by constructing the water surrounding myofibrils. Resulting in an unfrozen water increased, a high correlation between protein denaturation and amount of frozen water in almost all sugars were observed. The amount of unfrozen water may be increased ${ }^{7,8)}$ by the effect of cryoprotectant. It is thought that amount of frozen water will increase and the cryoprotective effect on denaturation of protein will be acquired from this if there is much $\mathrm{OH}$ groups. However, the different result was shown in this study. The cryoprotective effect of same sugar type even having same number of $\mathrm{OH}$ group, some differences have been observed.

Therefore, this suggests that aside from the rate that sugar plays in increasing amount of water surrounding myofibrils, some other factors may play a role in its cryoprotective effect. The molecular weight and the most suitable concentration of sugar also might contribute to structuring the water surrounding myofibrils. Further investigation is required to clarify the fact more precisely.

\section{REFERENCE}

1. Hanafusa N. Biological macromolecule and water, in "Foods and Water" (ed. by Japan Soc. Fisheries Sci), Koseisya Kouseikaku, Tokyo, 1973; 9-24 (in Japanese).

2. Akiba. M. Denaturation of protein and water activity, in "Foods and Water" (ed by Japan Soc. Fisheries Sci.), Koseisha Kouseikaku, Tokyo, 1973; 101-116 (in Japanese).

3. Matsuda Y. Water adsorption and stability of quality of fish meat power, in "Foods and Water" (ed. by Japan Soc. Fisheries Sci.), Koseisha Kouseikaku, Tokyo, 1973; $117-123$ (in Japanese).

4. Cheng CS and Parrish FC. Effect of postmortem storage conditions of nyofibrillar ATPase activity of porcine red and white semitendicosus muscle. J. Food Sci. 1978; 43: 17-21.

5. Kamal M, Watabe S, and Hashimoto K. Stability of sandine myofibrils during storage at various $\mathrm{pH}$ vahues. Nippon Strisan Gaikkaishi. 1990; 56: 83-90.

6. Katoh N, Uchiyama H, Tsukamoto S, Arai. K. A bjochemical study on fish myofibrillar ATPase. Nippon Suisan Gakkaishi. 1977; 43: 857-867.

7. Wakamatsu T, Satoh Y. Denaturation of unfreezable water in sucrose, sodium chloride and protein solutions by differential scanning calorimeter. Nippon Nogeikagaku Kaisht. 1979; 53 : 415-420.

8. Wakamatsu T., Satoh Y, Saitoh Y. Further Sturdy on the effect of sucrose an d sodium chloride on gelation and unfreezable water of egg yolk during freezing. Nippon Nogeikagaku Kaishi. 1979;54: 951-957. 